\title{
The Sabre in Spain through Fencing Treatises
}

\author{
Manuel Valle Ortiz \\ Universidade de Santiago de Compostela \\ gurnemanz@hotmail.es
}

\begin{abstract}
The sabre was introduced to Spain and other Hispanic countries from abroad, leading to the establishment of a Spanish sabre school based on the principles of Destreza. Several types of fencing books can be found. There were books on sabre instruction for the army and navy with simple techniques but also more developed works designed both for officers' fencing and duelling and or for civilian duelling, and later for sportive entertainment.

There are a considerable number of extant treatises, mainly available in continental Spain but also in the Americas. Many of the authors were army or navy officers who were also teaching in military institutions. The evolution of sabre fencing is followed until the beginning of the twentieth century.
\end{abstract}

Keywords - Sabre, Destreza, Spanish school, bibliography

\section{INTRODUCTION}

The Destreza is a fighting system that was developed in Hispanic countries during the end of the fifteenth century. It acquired a widespread distribution primarily in the parts of the world under Hispanic influence. The central weapon is the sword, alone or with other side arms (dagger, buckler, rotella, cape and many others), although its principles can be applied to any weapon (the montante, flail and polearms are specifically mentioned). The Destreza was a very long-lasting fencing tradition; it lasted well into the nineteenth century until it faded into oblivion, replaced by other contemporary schools of fencing. ${ }^{1}$

The swords of the early period of Destreza were very different to later ones, but we can see also that as new weapons like the sabre or bayonet were added, Destreza principles were stretched as far as possible to accommodate the new arms.

Besides the incorporation of the sabre to the Destreza tradition there were other practices inspired either by contemporary European schools and theories, or through the use of the sabre as a military weapon, with its own teaching methodology recorded in military regulations.

During the seventeenth century a considerable number of fencing publications were produced in Hispanic countries, most of them concerning Destreza sword. In the

\footnotetext{
* In order to ease the reading and diminish the number of footnotes, the author uses the reference system author-date in this article.

1 There is a detailed review in Valle Ortiz, "The Destreza Verdadera: a global phenomenon", pp. 324-353.
} 
eighteenth century very few books were published, but among them some dealt with the sabre. It is in the nineteenth century when again a lot of fencing books were published in Spain, this time with the sabre as one of the main subjects.

\section{EIGHTEENTH CENTURY}

In Spanish sources one of the first mentions of sabre fencing is in the book of Juan Nicolas Perinat (1758a), Arte de esgrimir florete y sable. This is a small oblong volume with plenty of plates: its purpose is to be the fencing instruction manual for the midshipmen at the naval academy of Cadiz. The smallsword is the intended weapon for officers while the sabre is for soldiers and sailors, but the knowledge of sabre fencing is useful for future officers because it can be used in some combat situations. For the most part it deals with smallsword fencing but the last pages are dedicated to very simple sabre fencing, describing only basic cuts and some advice for encounters with men wielding smallswords. At the end it describes La escaramuza, a technique for dealing with multiple opponents (Perinat, 1758a: 37).

The weapon represented on the plates is a naval cutlass type of sword.

The system described in the book is similar to contemporary French works (le Perche, 1750) and it is not based on Destreza theory. This book was issued as an attempt to replace the old Destreza tradition with modern weapons and techniques: during this period of the Enlightenment the Spanish Navy was a very innovative institution, introducing and updating new methods of engineering and navigating, whilst also making advances with tactics, geography and many other subjects. There are several manuscripts of this work, either original or copies, probably due to its use by the pupils of the naval school (Perinat, 1757) (Perinat, 1758b) (Perinat, s.XVIIIa) (Perinat, s.XVIIIb) (Perinat, s.XVIIIc).

The next mention we have of sabre fencing in Spain comes from the Encyclopedia Methódica, a translation of the French Encyclopedie Methodique, published in Madrid (Sanz, 1791) during a period of political upheaval that allowed for the introduction of some foreign books and ideas. Some years later, however, the Inquisition reacted, forbidding any further advancements and banning the introduction of the French Enciclopedie volumes into Spain. (Donato, 1992: 161)

In this book we have the translation of material already published in Angelo (1763), Girard, and other French sources. Specific instruction for the use of the sabre is not presented: rather, it is shown as a weapon to fight against (Sanz, 1791: 520). The plates engraved for this edition (Sanz, 1791b) follow the originals from the French edition with some minor changes. 


\section{NINETEENTH CENTURY}

One of the earliest references we have of sabre fencing in Hispanic countries is the Simon de Frias treatise (Frias, 1809). It is very interesting because it deals with civilian sabre fencing. It uses the Destreza terminology and was published in Mexico. All of this makes this work a very special example of the development of sabre fencing in Hispanic countries, and probably one of the last attempts to use the Destreza in a practical way. The author was a Destreza master, with the official title and having passed his examination. He claims that it is the first sabre book: in the foreword (Frias, 1809: xi) he mentions as forerunners Perinat (1738) and Angelo (1763) but says that they only showed the subject in a marginal way. The text, although it quotes Rada (Frias, 1809: 124, 193), presents guards, cuts, thrust and parries like conventional fencing schools: only the terminology following the Destreza patterns and the importance of aggression and disarming (Conclusión) remember the Destreza.

We have also the military works. One of the early sources is a book of plates demonstrating different aspects of military sabre for the cavalry, including Spanish army uniforms inspired by Napoleonic models (Vizcaino, 1819). This book comprises 40 plates and makes reference to paragraphs of the cavalry instruction manual from 1815 (Spain, 1815). This is the first time that a specific military method of training sabre was published in Spain. The manual instructs the soldier as to the basic principles of cuts and parries and also to particular situations such as defending the horse or fighting infantry. There is another edition of these lithographic plates printed in Barcelona (Vizcaino, 1820), one of the first lithographs printed in Spain.

In the nineteenth century many cavalry regulations included a section on the use of the sabre, starting with the Cavalry Regulations of 1815 (Spain, 1815), the first ones to include a section on sabre fencing and its teaching method.

In Spain the national militia required sabre instruction, so a chapter was included in a cavalry regulation manual (Breve instrucción, 1821: 61-84, 118-122).

Others followed (Spain, 1824) (Spain, 1825) (Spain, 1844) (Spain, 1847) (Spain, 1850) (Spain, 1851a) (Spain, 1851b).

In Manila (Philippines), then a Spanish colony, a manual for a local cavalry regiment, Lanceros de Luzon, which inclued sabre management was published (Spain, 1855).

More titles were published (Spain, 1861) (Spain, 1869a) (Spain, 1869b) (Spain, 1872) (Spain, 1876) (Spain, 1877) (Spain, 1880) (Spain, 1882) (Spain, 1886) (Spain, 1887a) (Spain, 1887b)

For the naval squadron based on Habana an English book was translated by Juan José Martínez, a navy officer (Martinez, 1832). This book is a translation of the manual used by General Keane in Jamaica, that itself was inspired by the work of Angelo (1819).

The military use of sabre was also recorded in Mexico, where a General and later president, Mariano Arista, published a book about sabre fencing on horseback, Teoria 
para el manejo del sable a caballo (Arista, 1840: ii). The author announces in the prologue to have taken inspiration from a French book, Théorie sur l'escrime a à cheval (Muller, 1816).

The military sabre was sometimes introduced following foreign patterns, as in the case of the translation of A progressive course on fencing by the French author François Bauge, that was eventually published in Cuba (Bauge, 1842).

A book published in Portugal (Osorio y Gomez, 1842) includes a section on sabre fencing on horseback. This book is a translation of a Spanish treatise (Thomase, 1823) but the horse plates are not included in the original.

Some works were intended for civilian use, mainly duelling, as shown by a manuscript from Pastor de Casal including fleuret and pistol (Pastor, 1840).

The short stick was used as an introduction to or a trainer for the sabre: some published books were devoted entirely or at least in part to this weapon, like that from Balbino Cortés, a retired captain (Cortés, 1851).

In 1854 José Cucala y Bruño, who belonged to the Destreza tradition (Teniente mayor del Reino y examinador en la Ciencia filososofica y matemática en la Destreza de las armas), published a fencing manual comprising several parts (Cucala, 1854). One of them is sabre fencing for infantry, developing a system very similar to French fencing. A section on sabre for cavalry presents a simpler method, mainly employing basic cuts and parries, and a section on sabre on horse against lance.

Jaime Merelo y Casademunt, a teacher of fencing in the infantry college, published a book on sabre fencing (Merelo, 1862) with a second edition (Merelo, 1879). This book is directed to the officers of the army. He follows the Destreza terminology, applying principles such as means of proportion, angles, movements, changes of line, disarms (conclusión), and even the atajo concept. This can be considered as one of the main exponents of the Spanish sabre school.

A brother of Jaime, José Merelo y Casademunt, also a teacher in several military academies, published a small oblong manual on Spanish sabre (Merelo 1878). He follows the same principles as his brother with Destreza-related terms and techniques, disarms (conclusión), and atajo.

A third Merelo, Alfredo, the son of José, also wrote a book on sabre fencing, the Manual de esgrima de sable y lanza (Merelo, 1880), intended for military officers. He also recorded the diagonal line changes and atajo as recommended techniques.

Some fencing books were presented as booklets in miscellaneous popular collections, achieving considerable success and several reprints in new editions. The Manual de Esgrima (Heraud, 1864) by Antonio Heraud y Clavijo de Soria was published again in 1877, 1892 and 1912. It includes several weapons: sword, sabre, fleuret, stick, and even dagger, cape and knife. It follows the standard divisions of cuts and parries and offers some council on duelling. 
In Portugal the work of Francisco Adolfo Celestino Soares appeared twice in a popular collection (Soares, 1883, 1898)

A small pamphlet from a divulgate collection includes very short comments on sabre fencing (Lorca, 1896).

Federico Gerona y Enseñat, a cavalry officer, wrote a book on sabre fencing (Gerona, 1877). In a second edition he added a chapter on horseback fencing (Gerona, 1882). The author was a pupil of Master Nicolas "el Zuavo" (Gerona, 1877: 10), an old French soldier established as a fencing master in Spain. The book is a simplification of current fencing techniques, eliminating any references to Destreza or its terminology.

In Portugal authors such as Adolfo Augusto Nandin de Carvalho, a naval officer who received education from the naval schools of Spain, Portugal and England, offered some aspects of military sabre in their writings. Carvalho specifies the use of naval sabre and bayonet sabre (Carvalho, 1878).

Liborio Vendrell y Eduart wrote a small treatise on sabre (Vendrell, 1879) where he disclaims all of the old schools, adopting modern and simplified ways of fencing.

Luis Cenzano y Zamora, an army officer, wrote the small Manual de esgrima de sable, (Cenzano, 1882). The scope of the book is instruction for military use, but he still uses Destreza terms like acute, obtuse and right angles, nails up, down, and in the air, and concepts like atajo and disarms (conclusion).

The same year appeared another manual of sabre, Enseñanza general de la esgrima del sable by José Cortés y Dominguez (Cortés, 1882). This author is credited with a manuscript regarding sabre fencing on horse (Cortés, 1883), but even today it remains unknown.

In America there were several books on sabre fencing, most of them written by army officers and directed towards its use in warfare or duelling. In Cuba an army officer, Luciano Aneiros Pazos, is said to have published a sabre fencing manual, Método de esgrima del sable (Aneiros, 1882). Although there are bibliographic references, I have not seen any copies.

A Spanish officer, Mariano Sabat y Fargas, emigrated to Uruguay where he joined the army, reaching the degree of colonel: he also taught fencing at the military college. $\mathrm{He}$ published a book on sabre fencing (Sabat, 1883).

In Habana, Don Eduardo Cuevas published a small treatise on sabre (Cuevas, 1887).

Sofanor Parra, a Chilean military officer, published a fencing manual for military use (Parra, 1889).

There is a further sabre fencing treatise from Chile (Esgrima general de sable, 1894). 
The Baron of Bischoffshausen, a military man of German origin also active in Chile, published Reglamento de esgrima de sable i lanza (Bischoffshausen, 1895) for the instruction of cavalry soldiers.

In Portugal appeared a manual for the army's fencing instruction by Antonio Domingos Pinto Martins (Martins, 1895). There are sections on sword, sabre, and fleuret but for the most part they are sport oriented.

Another Manual de esgrima was published by the Portuguese army the same year (Portugal, 1895).

C. León Broutin, a fencing master of French family origins, includes a chapter on sabre in his book on fencing (Broutin, 1894). It follows the French school and includes advice on duelling.

The book of Gegorio María Dueñas is a very brief treatise including some basic cuts and parries (Dueñas, 1895). It is intended mainly for use in duels, although the author shows he is not completely favourable towards them: he argues that in some cases it could be justified, even going so far as to state that is more humanitarian to kill a man than to maim him for life (Dueñas, 1895: 6).

Also focusing on the duel is the work of Adelardo Sanz, Esgrima del sable y consideraciones sobre el duelo (Sanz, 1886).

In the last years of the nineteenth century Antonio Álvarez García, an army officer who saw service first in Spain and later in Cuba, wrote several fencing treatises. Many of them are devoted to the sabre (Alvarez, 1882; Alvarez, 1886; Alvarez, 1892; Alvarez, 1896), and as the author explains in the introduction (Alvarez, 1892: 19), the sabre is a weapon most convenient for the defence of an officer using his regulation weapon or a civilian his walking stick. At the end of the book (Alvarez, 1896: 61) there is some advice on duelling, although the author discourages its practice as an outdated social convention.

The translation of French fencing manuals was a means of introducing foreign schools to Spain and other countries. In Argentina was published a translation of a book by F. Roussel, Tratado sobre la esgrima, florete y sable (Roussel, 1893).

Some French fencing manuals were translated very soon after their first appearance, as in the case of the Manual de esgrima florete espada y sable by Emile André (1897), published one year after the original French edition (Andre, 1896). There are reflections on the use of the sabre by soldiers, either as a weapon of war, or for the duel, although it was becoming less common by this time. The use of lighter sabres was favoured for sports training (Andre, 1897: 231-3).

At the same time translations of the Italian sabre manuals by Massaniello Parise were published in Mexico (Parise, 1898). 


\section{TWENTIETH CENTURY}

Many fencing manuals included a section on sabre. Pedro Carbonel, master of arms of King Alfonso XIII and very active at the turn of the century, wrote a book on fencing, Teoría y práctica de la esgrima, where every notion of Destreza is absent (Carbonel, 1900).

In Argentina the Italian master Scipione Ferretto published a book on sabre fencing (Ferretto, 1901). During the course of the century there was a growth of fencing and duelling in Argentina. Several Italian masters were established there, and the Jockey Club and Club de Gimnasia y esgrima become centres for the practice and learning of fencing (Gayol, 2005).

Although the duel was becoming less common, there were works focused on its practice with different arms, including the sabre, which were still being published. A book by a Spanish infantry captain was edited several times during the first years of the twentieth century (Sánchez-Melgar, 1902a, 1902b, 1904, 1907).

Several divulgative publications included sections on sabre fencing. This included a brief text by Felipe Navarro Izquierdo (Navarro, 1901), one by Antonio Viada, and another is to be found in Creus (1917). Other texts were published later in the twentieth century but focused on the sabre only as a sporting weapon.

\section{CONCLUSIONS}

The sabre made its appearance in Hispanic countries comparatively later than in other countries, mainly as a military weapon. There were attempts to incorporate the sabre into the Destreza system and so we can speak of a specific school of sabre fencing based on Destreza during the nineteenth century The influence of foreign books and translations were also introducing new systems of sabre fencing to Hispanic countries. The purpose of these books was oriented to the personal defence of military officers or duelling.

For the military use of sabre during the nineteenth century there are several published official regulations where the sabre is taught to soldiers, and directions as to its use are given.

By the end of the nineteenth century and during the twentieth century, the sporting application of sabre fencing was increasing, relegating the military sabre to a ceremonial use only. 


\section{BIBLIOGRAPHY}

The references to the bibliography of Valle Ortiz, Nueva bibliografía de la antigua esgrima $y$ destreza de las armas are signalled in brackets.

\section{VI.1. Primary sources}

Álvarez García, Antonio, Nociones de esgrima del sable español (Remedios: [s.n.], 1882) [Valle .6]

Álvarez García, Antonio, Tratado de esgrima de sable y florete (Jerez: Imp. el Cronista, 1886) [Valle .7]

Álvarez García, Antonio, Grandezas del arte de la esgrima (Habana: Imp. del E.M de la Capitanía General, 1892) [Valle .10]

Álvarez García, Antonio, Tratado de esgrima de sable y florete (Cárdenas: Imp. F. Pestana, 1896) [Valle .11]

André, Emile, Manuel théorique et practique d'Escrime (Fleuret, épée, sabre...) (Paris: Garnier frerès, 1896)

André, Emile, Manual de esgrima. Florete, espada y sable. Contiene varios capitulos acerca del asalto público, la esgrima italiana, los usos del duelo, la organización de la esgrima en Francia, la bistoria de la esgrima, etc. Por Emilio André, fundador de la revista l'Escrime française, traducido del original por Nicolás Estévanez (Paris: Garnier hermanos, 1897) [Valle .16]

Aneiros Pazos, Luciano, Método de esgrima del sable para la Sala de Armas militar de Matanzas. Recopilación de los mejores autores aumentada con quites tretas y golpes más oportunos, por el aficionado y director de la academia, Comandante de infantería D. Luciano Aneiros (Matanzas: Imp. el Ferrocarril, 1882) [Valle .18]

Angelo, Domenico, L'école des armes (London: R\&J. Dodsley, 1763)

Arista, Mariano, Teoria para el manejo del sable a caballo por el General de Brigada del Ejercito de la República Mejicana C. Mariano Arista (México: Juan Ojeda, 1840) [Valle .22]

Bauge, Francisco J., Curso progresivo de esgrima con el manejo del sable a pie y a caballo por D. Francisco J. Bange. Graduado en la escuela militar de Paris (Trinidad (Cuba): Imp. Cristobal Murtra e hijos, 1842) [Valle .32]

Bischoffshausen, E., Reglamento de esgrima de sable i de lanza por E Baron de Bischoffshausen. Profesor de Ejercito. Aprobado por decreto supremo de 26 de Septiembre de 1895 (Santiago de Chile: Imp. y encuadernación Barcelona, 1895) [Valle .35]

Breve instrucción de la táctica militar de caballería para que con facilidad y en corto tiempo puedan aprender a maniobrar y usar de sus armas los ciudadanos que componen las compañias de la milicia nacional local de dicha arma. Escogida del reglamento adoptado para la caballería del ejercito y ordenada enlazada y coordinada por el alférez de la misma Arma D.G.C. (Madrid: Imp. Minerva Española, 1821) [Valle .40] 
Broutin, Claude León, El arte de la esgrima por C. Leon Broutin, ex-profesor de la Academia del Estado Mayor del Ejercito, profesor del Centro del Ejercito y de la Armada, del Círculo de Bellas Artes, del Centro instructivo del obrero, Miembro correspondiente de l'Academie d'Armes de Paris (Madrid: Ricardo Fé, 1893) [Valle .41]

Carbonel, Pedro, Teoría y Práctica de la esgrima por Pedro Carbonel (Madrid: Sucesores de Rivadeneyra, 1900) [Valle .47]

Carvalho, Adolfo Augusto Nandin de, Manejo e esgrima de sabre naval e de sabre bayoneta, approvado e mandado adoptar em portaria de 27 de Junho de 1878 (Lisboa: Imprensa Nacional, 1878) [Valle .48]

Cenzano y Zamora, Luis, Manual de esgrima de sable. Recopilación de las principales tretas puesta por lecciones al alcance de todos los aficionados, por D Luis Cenzano Zamora, comandante capitán de ejercito, caballero de la Real muy Distinguida Orden de San Hermengildo, de Isabel la Catolica, Cruz de la Orden del mérito militar roja y blanca, etc. (Burgos: Imp. viuda de Villanueva, 1882) [Valle .65]

Cortés y Domínguez, José, Enseñanza general de la esgrima del sable, por el Comandante graduado Capitán de Caballería Don José Cortés y Dominguez. (Albacete: Imp. Luciano Ruiz, 1882) [Valle .80]

Cortés y Domínguez, José, Esgrima a caballo, segunda parte de la enseñanza general de la esgrima del sable, por el Comandante garduado, Capitán de Caballeria Don José Cortés y Dominguez. (MS., 1883) [Valle .81]

Cortés y Morales, Balbino, El palo y el sable o teoría para el perfeccionamiento del manejo del sable por la esgrima del palo corto (Madrid: Lit. de Zaragozano, 1851) [Valle .82]

Creus, Manuel F., Esgrima (Barcelona: Biblioteca Los Sports, 1917).

Cuevas, Eduardo, Lecciones de sable, por Don Eduardo Cuevas (Habana: Imp. la Tipografía, 1887) [Valle .88]

Donato, Clorinda, 'La Enciclopedia Metódica: la traduction espagnole de l'Encyclopédie méthodique', in Recherches sur Diderot et sur l'Encyclopédie, 12 (1992), 155-164

Dueñas, Gregorio María, Esgrima de sable por D, Gregorio María Dueñas, profesor de Esgrima de la antigua Academia de Infantería, de la extinguida Academia Militar General, de la suprimida Academia para Profesores de Armas, de la Escuela Central de tiro y en la actualidad de la Academia de Infantería (Toledo: Menor Hermanos, 1895) [Valle .106]

Esgrima general de sable (Santiago (Chile): Imp. y Enc. Chilena, 1894) [Valle .110]

Ferretto, Scipione, Esgrima italiana, primer tratado completo sobre esgrima de sable publicado en castellano (Buenos Aires: Tipo.lit. Angel Prina, 1901) [Valle .158]

Frias, Simón de, Tratado elemental de la Destreza del sable. Compuesto por Don Simón de Frias, Maestro de todas armas examinado aprobado y titulado por el superior gobierno de Nueva España (México: Imp. de Arizpe, 1809) [Valle .165]

Gerona y Enseñat, Federico, Esgrima del sable, escrita por el oficial de Caballería Don Francisco Gerona y Enseñat (Madrid: T. Fortanet, 1877) [Valle .182] 
Gerona y Enseñat, Federico, Esgrima del sable, escrita por el oficial de Caballería Don Francisco Gerona y Enseñat (Madrid: T. Fortanet, 1882) [Valle .183]

Girard, Pierre Jacques François, Noveau traité de la perfection sur la fait des armes (Paris: Charles Moétte, 1736)

Heraud y Clavijo de Soria, Antonio, Manual de esgrima en el que se trata de la esgrima de la espada, espada y daga, del sable, florete, del palo bastón y finalmente de la esgrima del fusil o carabina con bayoneta (Paris: Rosa et Bouret, 1864) [Valle .196]

Lorca-Diez, Román de, La esgrima de florete, espada y sable por el profesor Román de Lorca-Diez. (Barcelona: B. Bauza, [ca. 1896-1900]) [Valle .234]

Martínez, Juan José (Translator), Ejercicio del sable mandado observar poe el jefe de escuadra D. Angel Laborde y Navarro a bordo de los bajeles de S.M. del apostadero de la Habana. Traducido le inglés por el teniente de navio de la Real Armada Don Juan José Martines (Habana: Oficina de D. José Boloña, 1832) [Valle .255]

Martins, Antonio Domingos Pinto, Manual de esgrima para uso do exercito por Antonio Domingos Pinto Martins, Mestre d'armas de S. Magestade El-Rei e de S.S. Altezas, das escolas do exercito e naval, socio correspondente da Academia d'Armas de Paris (Lisboa: Livreria de Antonio Maria Pereira, 1895) [Valle .256]

Merelo y Casedemunt, Jaime, Tratado completo de la esgrima del sable español, por Don jaime Merelo y Casademunt, profesor de esgrima en el Colegio de Infanteria (Toledo: Imp. Severiano López Fando, 1862) [Valle .269]

Merelo y Casedemunt, Jaime, Tratado completo de la esgrima del sable español, por Don jaime Merelo y Casademunt, profesor de esgrima en el Colegio de Infanteria (Valencia: Imp. viuda de Ayoldi, 1879) [Valle .280]

Merelo y Casademunt, José, Manual de esgrima, recopilación de las tretas más principales que constituyen la verdadera esgrima del sable español y del florete, por D. José Merelo y Casademunt, profesor de esgrima que ha sido de varias academias militares y en la actualidad de la del cuerpo Administrativo del Ejercito (Madrid: R. Labajos, 1878) [Valle .281]

Merelo y Fornés, Alfredo, Manual de esgrima de sable y lanza para toda el arma de caballería y sable de infantería, por Alfredo Merelo y Fornés. Corregido y autorizado por su señor padre, profesor que ha sido de varias academias militares y que lo es en la actualidad de la del Cuerpo Administrativo del Ejercito (Madrid: M. Minuesa, 1880) [Valle ,283]

Muller, A., Théorie sur l'escrime à cheval pou se défendre avec avantage contre toute espèce d'armes blanches (Paris: Cordier, 1816)

Navarro Izquierdo, Felipe, Método para esgrimir en combate real o efectivo con un solo y seguro quite y reducidas tretas pero de seguros resultados. Un progreso en la esgrima del sable. Por D. Felipe Navarro izquierdo, Ex-oficial de Infantería auxiliar de Estado Mayor (Valencia: M. Ferreró y Cia., 1901) [Valle .303]

Osorio y Gómez, Pedro. Tractado de esgrima a pé e a cavallo en que se ensina por principios o manejo do florete ou o jogo da espada que se uza hoje (Lisboa: Typographia commercial, 1842) [Valle .313] 
Parise, Masaniello, Esgrima del sable. Edición especial de 1884. Traducida y arreglada para la clase de sable en el Colegio Militar por el capitán $2^{\circ}$ de E.M.E. D. Fortino M. Dávila (México: Imp. Hijas de J.F. Jens, 1898) [Valle .350]

Parra, Sofanor, Reglamento de esgrima del sable para la caballería del ejército por Sofanor Parra, Teniente coronel del regimiento de granaderos a caballo (Santiago de Chile: Imp. Nacional, 1889) [Valle .351]

Pastor de Casal, Julián, Instrucción para el manejo de sabre, florete y pistola, 1840 (MS. S.l., s.n.) [Valle .352]

Perche, Jean Baptiste le, L'exercice des armes ou le maniment du fleuret. Pour ayder la mémorie de ceux qui sont amateurs de cet art (Paris: Vve. de F. Cherau, 1750)

Perinat, Juan Nicolás, Arte de esgrimir florete y sable por los principios más seguros fáciles e inteligibles, 1757 (Madrid. B.Lazaro Galdiano M 6-2-20) [Valle, 360]

Perinat, Juan Nicolás Arte de esgrimir florete y sable por los principios más seguros fáciles e inteligibles (Cadiz: Imprenta de la Real Academia de Caballeros Guardiamarinas, 1758a) [Valle .365]

Perinat, Juan Nicolas. Arte de esgrimir florete y sable por los principios más seguros fáciles e inteligibles, 1758b (MS. Oviedo. B. Univ. Oviedo, M-18) [Valle .362]

Perinat, Juan Nicolás, [Tratado de esgrima en 36 láminas con su explicación enfrentada], s.XVIIIa (MS. Madrid, B.Nacional España, Mss/8803) [Valle .361]

Perinat, Juan Nicolas, [Tratado del espadín], s.XVIIIb (MS. Leuven, B. Univ. Leuven, 1541) [Valle .363]

Perinat, Juan Nicolas, [Tratado del espadín y primores en la esgrima del sable], s.XVIIIc (MS. Gorlin, 267) [Valle .364]

Portugal. Army, Manual de esgrima. Escola práctica de Infanteria (Lisboa: Imp. Nacional, 1895) [Valle .378]

Roussel, F., Tratado sobre la esgrima, florete y sable por F. Roussel, Maestros de sala y ex-profesor de la Academia de esgrima de Paris. Traducida del francés por D. Julio Brandam (Buenos Aires: Jacobo Peuser, 1893) [Valle .403]

Sabat y Fargas, Mariano, Filosofía del arte de la esgrima: la teoría y la práctica para defenderse y ofender con ventaja (Montevideo: Imp. a vapor La Nación, 1883) [Valle .407]

Sánchez-Melgar Navarro, Francisco, En la sala de armas. Tratado de esgrima de espada y sable en su aplicación al combate personal (Madrid: El Trabajo, 1902a) [Valle .414]

Sánchez-Melgar Navarro, Francisco, En la sala de armas y en el terreno. Tratado de esgrima de espada y sable en su aplicación al combate personal; reglas de frecuente uso en la solución de los lances de honor (Madrid: El Trabajo, 1902b) [Valle .415]

Sánchez-Melgar Navarro, Francisco, En la sala de armas y en el terreno. Tratado de esgrima de espada, de sable a pie y a caballo, en su aplicación al combate individual; instrucción para el tiro de pistola y revólver; reglas de frecuente uso en la solución de los lances de honor (Madrid: Imp.

Administración Militar, 1904) [Valle .416] 
Sánchez-Melgar Navarro, Francisco, En la sala de armas y en el terreno. Tratado de esgrima de espada, de sable a pie y a caballo, en su aplicación al combate individual; instrucción para el tiro de pistola y revólver; reglas de frecuente uso en la solución de los lances de bonor (Madrid: Imp.

Patronato huerfanos de Administración Militar, 1907) [Valle .417]

Sanz, Adelardo, Esgrima del sable y consideraciones sobre el duelo (Madrid: Imp. Fortanet, 1886) [Valle .419]

Sanz y Chanas, Gregorio Manuel (translator), Encyclopedia metódica. Artes académicos traducidos del francés al castellano: a saber, el arte de la equitación por don Baltasar de Irurzun; y el de baile, de esgrima y de nadar por don Gregorio Sanz (Madrid: Imp. de Sancha, 1791)

Sanz y Chanas, Gregorio Manuel (translator), [Encyclopedia metódica. Artes académicos. Esgrima. Láminas]. ([Madrid]: s.n., [1791b])

Soares, Francisco Adolfo Celestino, Esgrima ornada con 10 gravuras (Lisboa: David Corazzi, 1883) [Valle .432]

Soares, Francisco Adolfo Celestino, Esgrima ornada con 10 gravuras (Lisboa: Secção editorial da Companhia Nacional Editora, 1898) [Valle .433]

Spain. Army. Cavalry, Reglamento para el ejercicio y maniobras de la caballería (Madrid: Imp. Real, 1815) [Valle .118]

Spain. Army. Cavalry, Reglamento para el ejercicio y maniobras de la caballería (México: Martin Rivera, 1824) [Valle .119]

Spain. Army. Cavalry, Reglamento para el ejercicio y maniobras de la caballería (Madrid: Imp. Real, 1825) [Valle .120]

Spain. Army. Cavalry, Manejo de armas para la caballería (Madrid: Imp. Uzal y Aguirre, 1844) [Valle .121]

Spain. Army. Cavalry, Reglamento para el ejercicio y maniobras de la caballería (Madrid: Imp. y libreria de La Publicidad, 1847) [Valle .122]

Spain. Army. Cavalry, Reglamento para el ejercicio y maniobras de la caballería (Madrid: Imp. J. Martín Alegría, 1850) [Valle .123]

Spain. Army. Cavalry, Manual de instruccion de caballería para las clases de oficiales de dicha arma (Madrid: Establecimiento tipográfico militar, 1851a) [Valle .124]

Spain. Army. Cavalry, Manual de instruccion de caballería para las clases de sargentos y cabos de dicha arma (Madrid: Establecimiento tipográfico militar, 1851b) [Valle .125]

Spain. Army. Cavalry, Prontuario para el Regimento de Caballería Lanceros de Luqón (Manila: Anselmo Mateo, 1855) [Valle .126]

Spain. Army. Cavalry, Manual de instruccion de caballeria para las clases de oficiales de dicha arma (Madrid: Imp. Manuel Minuesa, 1861) [Valle .128]

Spain. Army. Cavalry, Manual de instruccion de caballeria para las clases de oficiales y tropa de la misma arma (Madrid: Imp. Manuel Minuesa, 1869a) [Valle .129]

Spain. Army. Cavalry, Reglamento para el ejercicio y maniobras de la caballeria (Madrid: Imp. Manuel Minuesa, 1869b) [Valle .130] 
Spain. Army. Cavalry, Manual de instruccion de caballeria para las clases de oficiales y tropa de la misma arma (Madrid: Imp. Manuel Minuesa, 1872) [Valle .131]

Spain. Army. Cavalry, Manual de instruccion de caballeria para las clases de oficiales y tropa de la misma arma (Madrid: Imp. Manuel Minuesa, 1876) [Valle .132]

Spain. Army. Cavalry, Manual de instruccion de caballeria para las clases de oficiales y tropa de la misma arma (Madrid: Imp. Manuel Minuesa, 1877) [Valle .133]

Spain. Army. Cavalry, Manual de instruccion de caballeria para las clases de oficiales y tropa de la misma arma (Madrid: Imp. Manuel Minuesa, 1880) [Valle .134]

Spain. Army. Cavalry, Reglamento para el ejercicio y maniobras de la caballería (Madrid: Imp. Dirección General de Caballeria, 1882) [Valle .135]

Spain. Army. Cavalry, Manual de instruccion de caballería para las clases de oficiales y tropa de la misma arma (Madrid: Imp. Manuel Minuesa, 1886) [Valle .136]

Spain. Army. Cavalry, Reglamento para el ejercicio y maniobras de la caballería (Madrid: Imp. Dirección General de Caballeria, 1887a) [Valle .137]

Spain. Army. Cavalry, Reglamento para el ejercicio y maniobras de la caballería (Madrid: Imp. Depósito de la Guerra, 1887b) [Valle .138]

Thomase, Eudaldo. Tratado de esgrima a pie y a acaballo, en que se enseña por principios el manejo del florete o el juego de la espada que se usa en el dia (Barcelona: Narcisa Dorca, 1823). [Valle $.445]$

Trelles, Carlos M, Bibliografía cubana del siglo XIX (Matanzas: Imp. Quirós y Estrada, 1912-5)

Vendrell y Eduart, Liborio, Arte de esgrimir el sable. Arreglado a los adelantos de la escuela moderna (Vitoria: Imp. y libreria de Elias Sarasqueta, 1879) [Valle .458]

Viada, Antonio, Manual de sport por Antonio Viada con un prólogo de Alejandro Saint-Aubin (Madrid: Adrián Romo, 1903) [Valle .461]

Vizcaino y Martínez Moles, Joaquín, Manejo del sable. Colección de 40 diseños litográficos que representan las diversas posiciones de este ejercicio a caballo, dedicado a sus compañeros de armas. por J.V.M de P. ([Paris]: s.n., 1819) [Valle .466bis]

Vizcaino y Martínez Moles, Joaquín, Manejo del sable. Colección de 40 diseños litográficos que representan las diversas posiciones de este ejercicio a caballo (Barcelona: Litografía de J.E. Monfort, [ca. 1820]) [Valle .466ter]

\section{VI.2. Secondary literature}

Gayol, Sandra, 'La violence élégante en Argentine', Nuevo Mundo Mundos Nuevos [online], Coloquios, (2005), <http://journals.openedition.org/nuevomundo/845>; accessed 14 September 2018. DOI: 10.4000/nuevomundo.845

Leguina y Vidal, Enrique de, Bibliografía e historia de la esgrima española (Madrid: Fortanet, 1904) 
Valle Ortiz, Manuel, Nueva bibliografía de la antigua esgrima y destreza de las armas (Santiago de Compostela: AGEA Edizer, 2012)

Valle Ortiz, Manuel, ‘The Destreza Verdadera: a global phenomenon', Late Medieval and Early Modern Fight Books: Transmission and Tradition of Martial Arts in Europe $\left(14^{\text {th }}-17^{\text {th }}\right.$ Centuries), ed. by Daniel Jaquet, Karin Verelst, and Timothy Dawson (Leiden: Brill, 2016), pp. 324-53 